PRETHODNO PRIOPĆENJE

UDK: $336:<338.23: 336.74>$

Petra Popek Biškupec, PhD

Alisa Bilal Zorić, MBA

\title{
OPTIMIZACIJA KORIŠTENJA INSTRUMENATA MONETARNE I MAKROPRUDENCIJALNE POLITIKE U SVRHU OČUVANJA STABILNOSTI FINANCIJSKOGA SUSTAVA
}

\author{
OPTIMIZATION OF USE OF MONETARY AND \\ MACROPRUDENTIAL POLICIES FOR PRESERVING \\ FINANCIAL SYSTEM STABILITY
}

\begin{abstract}
SAŽETAK: Zbog integriranosti i globalne povezanosti financijskih subjekata i tržišta, monetarna politika više nije dostatna za očuvanje financijske stabilnosti (posebice kod malih otvorenih zemalja poput Hrvatske) te je za postizanje i očuvanje financijske stabilnosti nužno uvesti makroprudencijalne mjere i instrumente. Obzirom da monetarna i makroprudencijalna politika u ostvarivanju svojih ciljeva djeluju na iste i/ili povezane varijable, nužno je koordinirati politike kako bi se smanjila odstupanja od ciljeva kod obje politike. U ovome radu je metodom nelinearnog kvadratnog programiranja dokazano da se kooperativnim modelom u kojemu monetarna i makroprudencijalna politika surađuju, cjenovna i financijska stabilnost ostvaruju uz niža odstupanja od zadanih razina nego u slučaju ne-kooperativnog modela gdje svaka politika izolirano ostvaruje svoj cilj. Suradnja je ostvarena optimalnom primjenom kamatne stope (kao glavnoga instrumenta monetarne politike) i kapitalnih zahtjeva (kao glavnoga instrumenta makroprudencijalne politike) uz utjecaj deviznoga tečaja.
\end{abstract}

KLJUČNE RIJEČI: financijska stabilnost, monetarna politika, makroprudencijalna politika.

ABSTRACT: Due to the integration and global interconnection of financial entities and markets, monetary policy is no longer sufficient for maintainig financial stability (especially in small open countries like Croatia). Hence, in order to achieve and maintain financial stability, it is necessary to introduce macroprudential measures and instruments. Since for achieving their objectives both monetary and macroprudential policies affect the same

Dr. sc. Petra Popek Biškupec, Veleučilište Baltazar Zaprešić, Vladimira Novaka 23, Zaprešić, e-mail: pbiskupec@bak.hr Alisa Bilal Zorić, MBA, Veleučilište Baltazar Zaprešić, Vladimira Novaka 23, Zaprešić, e-mail: abilal@ bak.hr 
and/or related variables, it is necessary to coordinate these policies to minimize deviations from their respective goals. This paper uses the method of nonlinear quadratic programming to prove that with a cooperative model in which monetary and macroprudential policies work together both objectives (price and financial stability) are achieved with lower deviation from the required level than in the case of non-cooperative model, where each policy individually achieves its goal. Cooperation is achieved using an optimal level of interest rate (as the main instrument of monetary policy) and capital requirements (as the main instrument of macroprudential policy), along with the impact of foreign exchange rates.

KEY WORDS: financial stability, monetary policy, macroprudential policy.

JEL: C61, E52, E58

\section{UVOD}

Očuvanje stabilnosti financijskoga sustava u cjelini posebice je dobilo na značaju nakon razvoja posljednje financijske krize. Pregrijavanje ekonomije i taloženje rizika koje je bilo, između ostaloga, povezano s pretjeranom kreditnom aktivnošću bankovnoga sustava rezultiralo je dubokom i dugotrajnom financijskom i gospodarskom krizom globalnih razmjera. U vrijeme uzleta u poslovnim i financijskim ciklusima većina subjekata financijskoga sustava percipira niže razine rizika, što u kombinaciji s većom vrijednošću imovine koja služi kao kolateral rezultira većim obujmom kreditiranja. Takav fenomen posebice dolazi do izražaja u bankocentričnim sustavima kakav je i financijski sustav Hrvatske. Iz perspektive financijskoga sustava u kojemu dominiraju banke kao glavne kreditne institucije, monetarna politika jedna je od ključnih regulatora koja uz cjenovnu stabilnost mora voditi računa i o financijskoj stabilnosti. Dosadašnji regulatorni okvir i monetarna politika koja je bila usredotočena na očuvanje cjenovne stabilnosti pokazali su se nedostatnim za superviziju suvremenoga, globalno integriranoga financijskog sustava. Iz toga proizlazi da je postojeću monetarnu politiku potrebno nadograditi i nadopuniti mjerama $\mathrm{i}$ instrumentima kojima će se djelovati na ukupnu stabilnost financijskoga sustava u cjelini (a ne samo stabilnost cijena), a takve značajke su pokazale mjere i instrumenti makroprudencijalne politike. Makroprudencijalna politika promatra financijski sustav u cjelini, uključujući odnos između financijskoga i realnoga sustava, proučava sistemski rizik i donosi instrumente za upravljanje tim rizikom (BIS Progress Report to G20, 2011) te je na taj način učinkovita u postizanju dugoročne stabilnosti financijskoga sustava u cjelini. Financijska stabilnost podrazumijeva stanje niske razine financijskih rizika koji svojom materijalizacijom mogu uzrokovati velike makroekonomske troškove. Prema Europskom odboru za sistemski rizik (ESRB, 2011), makroprudencijalna politika se odnosi na očuvanje stabilnosti financijskoga sustava u cjelini, uključujući jačanje otpornosti financijskoga sustava i smanjenje akumulacije sistemskoga rizika, čime osigurava doprinos financijskoga sektora održivom gospodarskom rastu.

Iako je mikroprudencijalni nadzor nužna i osnovna sastavnica svake politike koja se odnosi na očuvanje financijske stabilnosti, on ne uključuje povezanost i međusobnu izloženost financijskih subjekata, a upravo visok stupanj integracije i povezanosti poslovanja stvara veću izloženost rizicima i generira povećanje sistemskih rizika, čime potencijalno narušava otpornost i stabilnost financijskoga sustava u cjelini (ESB, 2016). Ograničen utjecaj monetarne politike posebice dolazi do izražaja u malim otvorenim gospodarstvima, poput Hrvatske, gdje 
je očuvanje stabilnosti deviznoga tečaja preduvjet za očuvanje financijske stabilnosti zbog visokoga stupnja euroizacije, što sužava manevarski prostor središnje banke u provođenju aktivne monetarne politike. Istraživanja su pokazala da su se instrumenti makroprudencijalnog karaktera pokazali posebice korisnim u zemljama s velikim udjelom kredita u stranim valutama (ili indeksiranim uz valutnu klauzulu), gdje visoki stupanj euroizacije negativno utječe na monetarni transmisijski mehanizam. U takvim gospodarstvima makroprudencijalni instrumenti pokazuju pozitivan učinak na djelotvornost monetarnih impulsa tako da djeluju na smanjenje kreditne aktivnosti u stranoj valuti (Brzoza-Brezina, Kolasa i Makarski, 2015.).

Cilj ovoga rada je dokazati korisnost koordinacije monetarne i makroprudencijalne politike u svrhu postizanja i očuvanja dugoročne stabilnosti financijskoga sustava u cjelini metodom optimizacije korištenja instrumenata monetarne i makroprudencijalne politike. Ovaj rad nudi kvantitativnu perspektivu učinkovitosti makroprudencijalnih instrumenata temeljenu na ekonomskoj teoriji. Doprinos postojećoj literaturi očituje se u dokazu da usprkos visokome stupnju euroizacije i ograničenome manevarskom prostoru monetarne politike, u maloj otvorenoj ekonomiji, primjenom makroprudencijalnih instrumenata središnja banka može aktivno doprinijeti makroekonomskim politikama i gospodarskome razvoju zemlje uz istodobno očuvanje cjenovne i financijske stabilnosti. Obzirom da svako gospodarstvo ima tendenciju kretanja u ciklusima odnosno protekom vremena izmjenjuju se razdoblja uzleta i padova u financijskim i poslovnim ciklusima, makroprudencijalni pristup regulaciji ne može izmijeniti prirodno kretanje trendova, no može utjecati na smanjenje oscilacija amplituda u ciklusima i spriječiti novu pojavu dubokih i dugotrajnih kriza uzrokovanih nestabilnostima u financijskome sustavu. No, protuciklična regulativa kojom se osigurava dovoljno kapitalnih i likvidnosnih amortizera u vrijeme blagostanja (čime se istodobno smanjuje vjerojatnost materijalizacije sistemskih rizika, tj. moguce posljedice njihove materijalizacije) mora biti usuglašena (koordinirana) s monetarnom politikom kako bi učinak primjene instrumenata bio pozitivan.

U ovome radu se metodom nelinearnog kvadratnog programiranja optimiziraju gubici proizašli iz istodobne primjene instrumenata monetarne i makroprudencijalne politike na primjeru Republike Hrvatske u razdoblju od 2000. do 2015. godine. Gubicima se smatraju odstupanja od ciljeva politika (očuvanje stabilnosti cijena odnosno stopa inflacije na godišnjoj razini $2 \%$, kao cilja monetarne politike i odstupanje od ciljane razine omjera kredita i BDP-a za ne više od 2 postotna boda od dugoročnoga trenda, kao cilja makroprudencijalne politike) te odstupanja od primjene instrumenata obiju politika. Nakon provedene analize, minimiziranjem odstupanja od ciljeva u kooperativnome modelu politika dokazano je da su gubici koji su proizašli iz kooperativne primjene instrumenata manji od onih gdje svaka politika primjenjuje instrumente individualno te je time potvrđeno da optimalna kombinacija instrumenata monetarne i makroprudencijalne politike dugoročno osigurava očuvanje financijske stabilnosti.

Rad je strukturiran na sljedeći način: poglavlje dva prikazuje pregled literature i dosadašnja empirijska i teorijska istraživanja vezana uz financijsku stabilnost i makroprudencijalnu politiku. Poglavlje tri daje pregled regulatornog protucikličnog okvira za male otvorene zemlje, na primjeru Hrvatske. U poglavlju četiri je prikazan i opisan model optimizacije korištenja instrumenata monetarne i makroprudencijalne politike metodom nelinearnog kvadratnog programiranja, a u poglavlju pet su izložena zaključna razmatranja i rezultati istraživanja. 


\section{PREGLED LITERATURE I DOSADAŠNJIH ISTRAŽIVANJA}

U novije vrijeme, a posebice od razvoja financijske krize 2007. godine, brojna teorijska i empirijska istraživanja bave se problematikom postizanja i očuvanja dugoročne stabilnosti financijskoga sustava. Stabilnost financijskoga sustava u cjelini, kao temelj ukupne ekonomske stabilnosti nekoga gospodarstva, posebice danas, dobiva na značaju zbog integracije i financijske liberalizacije tržišta na globalnoj razini, postojanja brojnih oblika financijskih instrumenata i proizvoda, intenzivne primjene sekuritizacije te potpune informatičke povezanosti i razvoja novih informatičkih tehnologija koje ubrzavaju financijske transakcije i povećavaju povezanost svih subjekata financijskoga sustava na globalnoj razini. Osim toga, visokome stupnju globalne integriranosti financijskoga sustava pridonosi postojanje različitih ekonomskih i monetarnih integracija kakvu predstavljaju Europska unija i eurozona te se stoga očuvanje financijske stabilnosti ne može više odnositi samo na politiku jedne zemlje, već se danas govori o makroprudencijalnim mjerama i instrumentima koji imaju učinak na prekogranično poslovanje financijskih institucija i tokove kapitala, čime utječu na održavanje stabilnosti financijskoga sustava na globalnoj razini.

Zbog ograničenja monetarne politike u suvremenome globalno integriranom financijskome sustavu, teorijska i empirijska istraživanja koja se odnose na stabilnost financijskoga sustava usmjerena su na pronalaženje mjera i instrumenata kojima se može očuvati stabilnost financijskoga sustava u cjelini te takva istraživanja većinom uključuju proučavanje netradicionalnih instrumenata monetarne politike, različitih kapitalnih kontrola te mjera $\mathrm{i}$ instrumenata makroprudencijalne politike. Primjena netradicionalnih monetarnih instrumenata pokazala se učinkovitom i u slučaju tržišnocentričnih i u slučaju bankocentričnih financijskih sustava. Angeloni i Faia (2009.) istražuju utjecaj prudencijalne regulacije i monetarne politike na bankovni sustav koristeći DSGE model. Autori ispituju interakciju monetarne politike i kapitalnih zahtjeva propisanih aktualnim Baselskim sporazumom. Autori uočavaju problem korištenja poluge koju banke intenzivno koriste u fazi gospodarskoga uzleta usprkos monetarnim restrikcijama. S druge strane, primjena protucikličnih kapitalnih zahtjeva je učinkovita, ali može samo djelomično utjecati na smanjenje korištenja poluge. Rezultati istraživanja pokazuju da se najveći učinak na smanjenje korištenja poluge postiže kombiniranom primjenom protucikličnih kapitalnih zahtjeva i instrumenata monetarne politike restriktivnoga obilježja. Kiyotaki i Moore (2008.), Adrian i Shin (2009.) i Gertler i Karadi (2011.) bave se istraživanjem modela u koje su ugrađeni makroprudencijalni instrumenti i netradicionalni instrumenti monetarne politike za tržišnocentrične financijske sustave, kao što je financijski sustav SAD-a. Sva tri istraživanja su pokazala da su netradicionalni instrumenti monetarne politike učinkoviti u razdoblju krize, ali stvaraju troškove koji dodatno opterećuju sustav te tako negativno djeluju na oporavak financijskih ciklusa.

U bankovnome sustavu EU problem intenzivnoga korištenja poluge u razdoblju blagostanja i uz to povezana labavija monetarna politika, zbog niže percepcije rizika negativno su utjecali na stabilnost financijskoga sustava, što je posebice došlo do izražaja materijalizacijom financijskih rizika te dovelo do razvoja financijske krize 2007. godine (Nikolov, 2012.). N'Diaye (2009.) istražuje makroekonomske koristi protuciklične makroprudencijalne politike koja se koristi kao potpora monetarnoj politici, s posebnim naglaskom na ekonomije s režimom fiksnoga deviznog tečaja. Provedeno istraživanje je pokazalo da se kombinacijom 
makroprudencijalne i monetarne politike može postići oporavak realnoga sektora bez opasnosti od razvoja inflacije (do koje može doći zbog ekspanzivne monetarne politike).

Uzleti i padovi u ciklusu cijena nekretnina u zemljama EU su se dosad pokazali kao glavni uzroci materijalizacije sistemskih rizika i okidači financijskih kriza. Obzirom da monetarna politika nije dostatna za sprječavanje nastanka balona cijena nekretnina, za buduće uravnoteženje cijena imovine i očuvanje makroekonomske stabilnosti neophodno je u sustav ugraditi makroprudencijalnu regulativu. (Hartmann, 2015.)

Pretjerana izloženost banaka sektoru građevinarstva u razdoblju od 2003. do 2009. godine (osobito u Hrvatskoj i zemljama srednje i istočne Europe) bio jedan od ključnih razloga povećanja ranjivosti cijeloga bankovnog sustava ${ }^{1}$. Stoga je posebno važno definirati mjere $\mathrm{i}$ instrumente kojima će se moći djelovati na cikluse cijena nekretnina te u budućnosti osigurati kvalitetniju strukturu kreditnoga portfelja koji će povećati otpornost banaka na šokove. Kannan, Rabanal i Scott (2009.) su istraživali djelovanje monetarne i makroprudencijalne politike u makroekonomskome modelu balona cijena nekretnina. Istraživanjem je potvrđeno da su kreditna aktivnost banaka, razina domaćih investicija i platna bilanca zemlje povezane s oscilacijama cijena imovine i mogu doprinijeti stvaranju cjenovnih balona imovine. Autori sugeriraju da se središnje banke kao monetarni regulatori trebaju usredotočiti na kretanja navedenih varijabli kako bi se spriječile prevelike oscilacije u uzletima i padovima ciklusa cijena imovine, što u konačnici može smanjiti oscilacije inflacije. Rezultati njihovoga istraživanja pokazuju da restriktivna monetarna politika u kombinaciji s dodatnim kapitalnim zahtjevima (kao instrumentom makroprudencijalne politike) može učinkovitije utjecati na sprječavanje stvaranja cjenovnih balona u razdoblju blagostanja i uzleta u poslovnim ciklusima. Utjecaj makroprudencijalne regulacije i monetarne politike na cijene imovine istražuju i Canuto i Cavallari (2013.) te utvrđuju da se najveća djelotvornost obiju politika, u uvjetima ciljanja inflacije i fluktuirajućeg režima deviznoga tečaja, postiže kombinacijom makroprudencijalne regulacije i monetarne politike, koje zajedno mogu smanjiti procikličnost subjekata financijskoga sustava. Smanjenje procikličnoga ponašanja subjekata utječe na smanjenje oscilacija cijena imovine.

Protuciklični kapitalni i likvidnosni amortizeri glavna su odrednica makroprudencijalne politike. Upravljanje i smanjenje sistemskih rizika uglavnom je povezano s politikom formiranja sigurnosnih kapitalnih i likvidnosnih zaliha u obliku amortizera. Protuciklična makroprudencijalna politika se odnosi na propisivanje većih razina amortizera (kapitalnih i likvidnosnih zahtjeva) u razdoblju uzleta financijskih ciklusa te u otpuštanju amortizera u razdoblju pada u financijskim ciklusima. Benes, Laxton i Mongardini (2016.) su testirali učinkovitost makroprudencijalne regulacije u slučaju snažne oscilacije cijena stambenih nekretnina. Autori su dokazali da makroprudencijalni instrumenti kao što su protuciklični amoritizeri i ograničenja omjera kredita i vrijednosti kolaterala učinkovito sprječavaju precjenjivanje nekretnina i stvaranje cjenovnih balona.

Problem financijske stabilnosti usko je povezan i s postojanjem asimetričnih informacija na financijskim tržištima. U slučaju postojanja asimetričnih informacija, banke i dužnici su skloniji procikličnome ponašanju, usprkos, jer niža percepcija rizika i više cijene

Autorice prema podacima kreditne aktivnosti banaka na temelju podataka iz Biltena o bankama br. 6 do br. 19, dostupno na: http://www.hnb.hr/analize-i-publikacije/redovne-publikacije/bilten-o-bankama, [12. 12. 2016.]. 
imovine dovode do korištenja poluge na višoj razini, veće kreditne aktivnosti i većoj sklonosti zaduživanja, što dovodi do taloženja rizika i financijske ranjivosti. Povećanje ranjivosti financijskih institucija na agregatnoj razini znači da bilo koji šok ili nestabilnost mogu dovesti do većega i dugotrajnijega poremećaja svih ekonomskih varijabli (IMF, 2013a). Problematikom asimetričnih informacija i makroprudencijalnom regulacijom bavi se i Derviz (2013.) u neoklasičnome ekonomskom modelu. Autor promatra kreditnu aktivnost banaka te zaključuje da makroprudencijalna politika putem kapitalnih zahtjeva uspješno smanjuje negativne učinke u slučaju materijalizacije rizika (čije se taloženje generira zbog asimetričnih informacija) čime ublažava pojavu cjenovnih mjehura. Rezultat provođenja makoprudencijalne restriktivne politike je smanjenje financijske poluge, no s druge strane, makroprudencijalno stezanje može dovesti do kontrakcije u gospodarskoj aktivnosti realnoga sektora jer visoki regulatorni troškovi smanjuju ponudu kredita. Obzirom da subjekti na financijskim tržištima ne mogu samostalno riješiti problem asimetričnosti informacija, makroprudencijalna politika može protucikličnim kapitalnim i likvidnosnim zahtjevima utjecati na sprječavanje precjenjivanja imovine i time smanjiti asimetričnosti u odnosu informacija koje imaju dužnik i vjerovnik. (IMF, 2013a)

Sva dosadašnja teorijska i empirijska istraživanja pokazuju da je djelotvornost monetarne i makroprudencijalne politike veća ako su ciljevi i instrumenti obiju politika usuglašeni, jer u tome slučaju makroprudencijalna politika djeluje kao potpora i dopuna monetarnoj politici. Obzirom da djeluju na iste i/ili povezane varijable, $u$ interakciji monetarne i makroprudencijalne politike, monetarna politika mora zadržati neovisnost i kredibilitet, jer je očuvanje cjenovne stabilnosti (kao temeljni cilj monetarne politike) preduvjet za očuvanje ukupne financijske stabilnosti. U slučaju gdje je postavljen jasno definiran makroprudencijalni regulatorni okvir, monetarna politika lakše i bolje izvršava svoje ciljeve i zadatke jer je protucikličnim amortizerima osigurana stabilnost u slučaju pojave šoka te središnje banke nisu opterećene politikom držanja niskih kamatnih stopa u svrhu oporavaka financijskih i realnih ciklusa. (IMF, 2013b, IMF, 2014.)

Angelini, Neri i Panetta (2012.) su postavili teorijski model u kojemu su analizirali učinkovitost makroprudencijalne politike te interakciju makroprudencijalne i monetarne politike. Model se sastoji od dva cilja; očuvanje cjenovne stabilnosti (kao cilj monetarne politike) i minimiziranje odstupanja od omjera kredita i proizvodnje (kao cilj makroprudencijalne politike). Autori testiraju djelotvornost instrumenata omjer kredita i vrijednosti kolaterala i protucikličnih zahtjeva te utvrđuju da su instrumenti monetarne i makroprudencijalne politike djelotvorniji ako su međusobno koordinirani.

Koordinacija monetarne i makroprudencijalne politike je osobito važna u snižavanju makroekonomskih troškova koji se javljaju u razdobljima velikih fluktuacija poslovnih i financijskih ciklusa. De Paoli i Paustian (2013.) analiziraju utjecaj monetarne i makroprudencijalne politike u snižavanju makroekonomskih troškova u uvjetima nominalne rigidnosti i kreditnih ograničenja. Autori pokazuju da makroprudencijalni instrumenti pomažu očuvati makroekonomsku stabilnost u srednjem roku. Kratkoročno, veća je učinkovitost instrumenata monetarne politike te je zbog toga prilikom kreiranja monetarne i makroprudencijalne politike iznimo važno uzeti u obzir ročnu učinkovitost pojedinih instrumenata i koordinirati instrumente s obzirom na razdoblje u kojemu će polučiti efekte primjene. 


\section{PROTUCIKLIČNI REGULATORNI OKVIR MALIH OTVORENIH ZEMALJA - PRIMJER HRVATSKE}

Eksterna financijska liberalizacija doprinijela je manjoj učinkovitosti monetarne politike malih otvorenih zemalja te utjecala na slabljenje djelotvornosti većine kanala monetarnog prijenosa. Zbog uvozne ovisnosti i visokoga stupnja euroizacije mala otvorena gospodarstva, poput Hrvatske, ne mogu aktivno provoditi monetarnu politiku zbog usredotočenosti na očuvanje stabilnosti deviznoga tečaja. Stabilnost deviznoga tečaja je nužna zbog očuvanja stabilnosti potrošačkih cijena uvoznih proizvoda te sprječavanja razvoja inflacije na domaćemu tržištu (Ito i Sato, 2006.). Taj fenomen je posebice prisutan u Hrvatskoj gdje promjena razine deviznoga tečaja ima snažan utjecaj na promjenu cijena domaćih proizvoda (Posedel i Tica, 2007.). Problem istodobnog očuvanja stabilnosti deviznoga tečaja, cjenovne i financijske stabilnosti u Hrvatskoj može se riješiti primjenom makroprudencijalnih instrumenata. Makroprudencijalna regulacija koja se i prije nastupa posljednje financijske krize provodila u obliku kapitalnih kontrola pokazala je da usprkos ograničenjima monetarne politike, male otvorene i visokoeuroizirane zemlje mogu očuvati cjenovnu stabilnost, stabilnost deviznoga tečaja i ukupnu financijsku stabilnost (Radošević, 2010.). No, dio ekonomskih stručnjaka smatra da kapitalne kontrole (kao prudencijalni instrumenti) ipak nisu u skladu sa suvremenim slobodnim kretanjima kapitala na financijskim tržištima jer poskupljuju cijenu kapitala i na taj način povećavaju negativne eksternalije i neefikasnost. Fratzscher (2012.) tvrdi da je u slučaju potpuno učinkovitoga financijskog tržišta kapital optimalno alociran te bilo kakva intervencija izaziva poremećaje toga tržišta. Usprkos tome, upotreba kapitalnih kontrola i instrumenata makroprudencijalnoga obilježja je opravdana ako liberalizirani tokovi kapitala zbog svoje volatilnosti destabiliziraju makroekonomsku ravnotežu zemlje. U tome slučaju kapitalne kontrole postaju mjere prudencijalne politike središnje banke kojima se smanjuju nesavršenosti tržišta, sprječavaju prekogranična prelijevanja negativnih trendova (sprječava širenje zaraze) te kao takve, kapitalne kontrole utječu na smanjenje sistemskoga rizika, djeluju protuciklično i mogu se smatrati instrumentima kojima se povećava stabilnost financijskoga sustava (Radošević, 2013.). Korištenjem kapitalnih kontrola kao prudencijalnim instrumentima, Hrvatska je nakon provedene interne i eksterne liberalizacije financijskoga sustava te u razdoblju najveće kreditne ekspanzije od 2004. godine do 2008. godine, ipak uspjela očuvati stabilnost deviznoga tečaja te cjenovnu i financijsku stabilnost.

Zbog međusobne povezanosti i umreženosti financijskih institucija, banke kao glavne kreditne institucije europskoga financijskog sustava, pripadaju velikim međunarodnim grupacijama, što im omogućuje laku supstituciju izvora financiranja. Na taj način one mogu provoditi poslovnu politiku (primjerice, politiku kreditne ekspanzije) neovisno o karakteru monetarne politike, što onda čini monetarnu politiku neučinkovitom. (HUB, 2009.)

Problem pretjerane kreditne aktivnosti usko je povezan s pregrijavanjem ekonomije i taloženjem rizika, posebice makroekonomskih kao što su tečajni rizik (koji se javlja u zemljama s visokim stupnjem euroizacije zbog aprecijacijskih pritisaka domaće valute uzrokovanih dotokom stranoga kapitala ili deprecijacijskih pritisaka domaće valute uzrokovanih odljevom stranoga kapitala), rizik bijega kapitala (deprecijacija domaće valute može uzrokovati lošu investicijsku klimu i izazvati bijeg kapitala iz zemlje), rizik porasta ranjivosti financijskoga sustava (unutarnji i vanjski šokovi mogu zbog provedene liberalizacije 
dovesti do nemogućnosti servisiranja inozemnih obveza malih otvorenih zemalja), rizik zaraze (nestabilnosti i negativni trendovi iz zemalja odakle kapital dolazi lako se prelijevaju u male otvorene zemlje) (Radošević, 2013.). Zbog ovisnosti o stranome kapitalu i ograničenoj učinkovitosti monetarne politike, Hrvatska je u određenim razdobljima primjenjivala različite mjere kapitalnih kontrola prikazane u tablici 1. koje su imale makroprudencijalni karakter kako bi poboljšala učinkovitost monetarne politike.

Tablica 1: Kapitalne kontrole korištene kao makroprudencijalni instrumenti u Hrvatskoj

\begin{tabular}{|c|c|c|}
\hline Vrsta kapitalne kontrole & Opis i namjena & Razdoblje primjene \\
\hline $\begin{array}{l}\text { Ograničenje kupovine } \\
\text { vrijednosnica središnje banke } \\
\text { i Ministarstva financija } \\
\text { nerezidentima }\end{array}$ & $\begin{array}{l}\text { Nerezidentima nije dozvoljena } \\
\text { kupovina vrijednosnica središnje } \\
\text { banke i Ministarstva financija }\end{array}$ & Do 2006. \\
\hline $\begin{array}{l}\text { Ograničenje otvaranja } \\
\text { depozitnih računa rezidenata } \\
\text { u inozemstvu }\end{array}$ & $\begin{array}{l}\text { Nije dozvoljeno otvaranje } \\
\text { depozitnih računa rezidenata u } \\
\text { inozemstvu }\end{array}$ & Do 2011. \\
\hline $\begin{array}{l}\text { Minimalno potrebna devizna } \\
\text { potraživanja }\end{array}$ & $\begin{array}{l}\text { Djeluje na smanjenje valutne } \\
\text { neusklađenosti imovine i } \\
\text { obveza banaka odnosno valutne } \\
\text { neusklađenosti novčanog tijeka } \\
\text { banaka (dopušteno korištenje } \\
\text { financijskih izvedenica) } \\
\end{array}$ & $\begin{array}{l}\text { Od 2004. do 2012.: } 35 \% \text {; } \\
\text { od 2012. do 2015.: 28,5\%; } \\
\text { od 2015: } 17 \%\end{array}$ \\
\hline $\begin{array}{l}\text { Granična obvezna rezerva } \\
\text { na inozemno zaduživanje } \\
\text { banaka }\end{array}$ & $\begin{array}{l}\text { Djeluje na smanjenje } \\
\text { inozemnoga zaduživanja } \\
\text { banaka i smanjenje njihove } \\
\text { kreditne aktivnosti, smanjenje } \\
\text { aprecijacijskih pritisaka na } \\
\text { domaću valutu } \\
\end{array}$ & Od 2004. do 2008. \\
\hline $\begin{array}{l}\text { Ograničenje odobravanja } \\
\text { kratkoročnih kredita } \\
\text { nerezidentima }\end{array}$ & $\begin{array}{l}\text { Nije dozvoljeno odobravanje } \\
\text { kratkoročnih kredita } \\
\text { nerezidentima }\end{array}$ & $\begin{array}{l}\text { Do 2009. (od 2009. } \\
\text { nerezidentima je } \\
\text { dozvoljeno odobravati } \\
\text { kratkoročne kredite, ali ne } \\
\text { s rokom dospijeća kraćim } \\
\text { od tri mjeseca²) } \\
\end{array}$ \\
\hline $\begin{array}{l}\text { Visoka stopa obvezne } \\
\text { rezerve i propisano } \\
\text { upravljanje valutnom } \\
\text { strukturom }\end{array}$ & $\begin{array}{l}\text { Sprječava odljev kapitala i } \\
\text { smanjuje valutnu neusklađenost } \\
\text { imovine i obveza banaka }\end{array}$ & $\begin{array}{l}\text { 2003. - 2005.: } 19 \% ; \\
\text { 2005. - 2006.: } 18 \% ; 2006 . \\
-2009 .: 17 \% ; 2009 .- \\
\text { 2010.: } 14 \% ; 2010 .-2012: \\
13 \% ; 2012 .-2014 .: 13,5 \\
\% ; 2014 .-2015 .: 12 \%\end{array}$ \\
\hline
\end{tabular}

Izvor: autorice prema: Radošević, D. (2010.) Strategija liberalizacije kapitalnih tokova Hrvatske s inozemstvom, Ekonomski pregled, Vol. 61, No. 12, str. 725.-768.; Zakon o deviznom poslovanju (2003.), dostupno na: http://narodne-novine.nn.hr/clanci/sluzbeni/2003_06_96_1217.html, [26. 9. 2016.]; Zakon o izmjenama i dopunama zako-

Prema Uredbi o izmjenama i dopunama Zakona o deviznom poslovanju, NN 121/2009., dostupno na: http://narodne-novine.nn.hr/clanci/sluzbeni/2009_12_153_3762.html, [26. 9. 2016.]. 
na o deviznom poslovanju (2006.), dostupno na: http://narodne-novine.nn.hr/clanci/sluzbeni/2006_12_132_2955. html, [26. 9. 2016.]; Uredba o izmjeni Zakona o deviznom poslovanju (2009.), dostupno na: http://narodne-novine. nn.hr/clanci/sluzbeni/2009_12_153_3762.html, [26. 9. 2016.]; Hrvatska narodna banka: Pregled mjera i instrumenata monetarne politike, dostupno na: http://old.hnb.hr/monet/hmonet.htm, [27. 9. 2016.].

Uz kapitalne kontrole, drugi važan instrument makroprudencijalne politike koji se pokazao učinkovitim u Hrvatskoj su kapitalni zahtjevi. Borio i Zhu (2008.) analiziraju promjene u razvoju financijskoga sustava te zaključuju da je zbog sve manje učinkovitosti monetarnih mjera i instrumenata kojima se može osigurati dugoročna stabilnost financijskoga sustava, potrebno uvesti prudencijalne kontrole u transmisijski mehanizam monetarne politike, a to se osobito odnosi na mjere i instrumente za regulaciju kapitala. Zbog visoke razine euroizacije i valutno induciranoga kreditnog rizika, Hrvatska narodna banka je propisivala visoku stopu kapitalnih zahtjeva i prije razvoja posljednje financijske krize. Tako je stopa adekvatnosti jamstvenoga kapitala do 2010. godine morala iznositi najmanje $10 \%$, od 2010. do 2013. godine najmanje $12 \%$, a 2013. godine donesena je odluka o dodatnim i zaštitnim protucikličkim slojevima kapitala čime je dodatno ojačana stabilnost bankovnoga sustava. (Zakon o kreditnim institucijama (2008.), Zakon o kreditnim institucijama (2013.))

Nova struktura regulatornoga okvira u očuvanju dugoročne financijske stabilnosti temelji se na protucikličkome aspektu i instrumentima kojima se učinkovito djeluje na smanjenje i upravljanje sistemskim rizicima.

Ovisno o cilju koji se želi postići, makroprudencijalni instrumenti dijele se u kategorije (The ESRB Handbook on operationalising macro-prudential policy in the banking sector, 2013.):

a) instrumenti kojima se ograničava ukupna kreditna aktivnost i poluga (protuciklički kapitalni zahtjevi, ograničenje korištenja poluge); b) instrumenti kojima se ograničava sektorska kreditna aktivnost i poluga, na primjer kreditiranje sektora građevinarstva i kupoprodaje nekretnina (ograničenja omjera vrijednosti kolaterala i iznosa kredita, ograničenja omjera dohotka i iznosa kredita); c) instrumenti kojima se ograničava ročna neusklađenost imovine i obveza banaka (dodatni likvidnosni zahtjevi, ograničenja omjera vrijednosti kolaterala i iznosa kredita); d) instrumenti kojima se utječe na smanjenje moralnoga hazarda (kapitalni i protuciklički zahtjevi, jačanje vlastitoga kapitala).

Iako su raspon i djelovanje makroprudencijalnih instrumenata vrlo široki i kompleksni, instrumente makroprudencijalne politike općenito se može podijeliti u dvije osnovne skupine; a) instrumenti za upravljanje likvidnošću i kreditnom aktivnošću banaka i b) instrumenti za održavanje adekvatnosti kapitala banaka. Obje skupine makroprudencijalnih instrumenata sadržavaju komponentu protuciklične politike i politike upravljanja sistemskim rizicima. Namjera makroprudencijalne politike je formirati kapitalne i likvidnosne amortizere u vrijeme uzleta u poslovnim ciklusima, zbog čega makroprudencijalna politika zahtijeva više izdvajanja i čime se protuciklično djeluje na fazu ciklusa te sprječava pregrijavanje ekonomije i taloženje sistemskih rizika. U vrijeme pada u poslovnim ciklusima dolazi do otpuštanja kapitalnih i likvidnosnih zahtjeva te se na taj način potiče brži oporavak kreditnih ciklusa i pridonosi bržemu oporavku cijeloga gospodarstva.

Hrvatska je primjer zemlje koja je intenzivno koristila makroprudencijalne instrumente u obliku kapitalnih kontrola i protucikličnih regulatornih zahtjeva i prije izbijanja krize, upravo zbog ograničene djelotvornosti instrumenata monetarne politike. Korištenjem instrumenata kao što su visoke stope obvezne rezerve, uvođenje granične obvezne pričuve, 
obvezni upis blagajničkih zapisa, viša razina minimalno potrebnih deviznih potraživanja, ograničenja kreditnoga rasta determinirana zahtjevima za upravljanje kreditnim rizikom, zahtjevi za održavanjem minimalnoga koeficijenta likvidnosti, limitiranjem neto otvorenih pozicija, upravljanje valutnom strukturom izdvajanja i održavanja obvezne pričuve, Hrvatska narodna banka je ograničavala kreditni rast i prije izbijanja krize 2007. godine. (Lovrinović i Ivanov, 2009.; Lim et al., 2011.; Hrvatska narodna banka, 2013a.)

Obzirom da se kao makroprudencijalni instrumenti mogu koristiti razne mjere, aktivnosti i instrumenti monetarne i mikroprudencijalne regulacije te kapitalne kontrole (ako takvi instrumenti imaju protuciklični karakter i ako se koriste suprotno od faze financijskoga ciklusa) vrlo lako može doći do preklapanja korištenja različitih instrumenata na istim ili povezanim varijablama te oprečnoga djelovanja monetarne i makroprudencijalne politike. Prema tome, osim uvođenja instrumenata protucikličnoga makroprudencijalnog karaktera, za postizanje dugoročne i održive stabilnosti financijskoga sustava u cjelini, nužno je koordinirati mjere i instrumente makroprudencijalne i monetarne politike kako bi instrumenti djelovali u istome smjeru, a ne se međusobno poništavali i umanjivali učinkovitost obiju politika. Potreba koordinacije monetarne i makroprudencijalne politike proizlazi iz činjenice da i monetarna i makroprudencijalna politika u ostvarenju svojih ciljeva djeluju na iste ili povezane varijable te ako ove dvije politike nisu koordinirane postoji mogućnost izostanka željenih učinaka. Obzirom da je temeljni cilj monetarne politike cjenovna stabilnost, a temeljni cilj makroprudencijalne politike financijska stabilnost, ove dvije politike nisu supstituti, već se jedna nadograđuje na drugu. Iz toga razloga, potrebno je koordinirati korištenje instrumenata tako da se minimiziraju odstupanja od ciljeva jedne i druge politike.

Interakcija monetarne i makroprudencijalne politike najviše dolazi do izražaja kod djelovanja na kreditnu aktivnost banaka putem kanala kamatnjaka, kanala preuzimanja rizika i kanala kapitala. U sva tri slučaja može doći do oprečnoga djelovanja monetarne i makroprudencijalne politike čime se umanjuje učinkovitost u ostvarivanju ciljeva obiju politika. U visokoeuroiziranim zemljama, kanal kamatnjaka domicilne središnje banke obično ne djeluje. No, nakon razvoja posljednje financijske krize, ,snižavanje stope obvezne rezerve, spuštanje eskontne stope (a time i visine stope zakonske zatezne kamate od lipnja 2011.) te praksa aktualne nulte-kamatne stope na prekonoćne depozite banaka kod središnje banke, ipak pridonose niskoj cijeni zaduživanja na novčanome/međubankovnome tržištu“ te takav niži regulatorni trošak smanjuje kamatnjake na kredite banaka. (Ivanov, 2014; 90) Agur i Demetris (2012.) proučavaju utjecaj kanala kamatnjaka na financijsku stabilnost i zaključuju da s jedne strane visoke kamatne stope poskupljuju izvore financiranja likvidnosti banaka, što utječe na smanjenje kreditne aktivnosti i povećanje financijske stabilnosti, no, s druge strane, veći troškovi financiranja dovode do manje profitabilnosti banaka, što može uzrokovati bijeg kapitala i dovesti do problema i pojave nestabilnosti u financijskome sustavu. Altunbas, Gambacorta, i Marques-Ibanez (2014.) govore o kanalu preuzimanja rizika kao novome kanalu monetarne transmisije koji proizlazi iz kanala kamatnjaka. U razdoblju niskih kamatnih stopa javlja se sklonost banaka većim zaradama, novčani tokovi dužnika čine se boljima, a imovina koja služi kao kolateral za odobravanje kredita ima veću tržišnu vrijednost. Sve to zajedno pridonosi nižoj percepciji rizika, što povlači veću kreditnu aktivnost i na strani ponude i na strani potražnje za kreditima. Kapitalni zahtjevi, kao instrument kojim se regulira udio vlasničkoga kapitala u odnosu na dužnički, utječu na financijsku stabilnost tako da povećanje razine kapitalnih zahtjeva povećava ukupnu stabilnost financijskoga sustava. S druge strane, visoki kapitalni zahtjevi smanjuju kreditnu aktivnost 
banaka što negativno djeluje na financiranje realnoga sektora i ukupnoga gospodarstva te dugoročno može izazvati silazne trendove u poslovnim ciklusima. (Agur i Demetriz, 2012.)

Obzirom da monetarna i makroprudencijalna politika interaktivno djeluju na održavanje cjenovne i financijske stabilnosti, potrebno je optimalno uskladiti njihovo djelovanje.

\section{MODEL OPTIMIZACIJE INSTRUMENATA MONETARNE I MAKROPRUDENCIJALNE POLITIKE}

Optimizacija instrumenata monetarne i makroprudencijalne politike postiže se kada se istodobnom primjenom instrumenata obiju politika ostvaruju njihovi ciljevi, a da su pritom odstupanja od vrijednosti tih ciljeva minimalna. Odstupanja od ciljeva predstavljaju gubitke, jer veća odstupanja znače manju učinkovitost instrumenata u ostvarivanju ciljeva. Manja učinkovitost instrumenata rezultat je istodobnog djelovanja, koje nije koordinirano, monetarne i makroprudencijalne politike na iste i/ili povezane varijable. Nastavno na model koji su postavili Angelini i sur. (2012.), u ovome radu se prikazuju prednosti optimizacije instrumenata $\mathrm{u}$ istodobnom ostvarivanju ciljeva monetarne i makroprudencijalne politike metodom nelinearnog kvadratnog programiranja. Model analizira interakciju monetarne i makroprudencijalne politike u ostvarivanju ciljeva. Smatra se da su politike uspješno ostvarile svoje ciljeve ako su odstupanja od zadanih ciljeva minimalna. Instrumenti koji se pritom koriste su u slučaju monetarne politike kamatna stopa, a u slučaju makroprudencijalne politike kapitalni zahtjevi. Za razliku od prvotnoga modela u kojemu se kao cilj makroprudencijalne politike koristi rast BDP-a, u ovome radu se kao cilj makroprudencijalne politike koristi odstupanje omjera kredita i BDP-a za 2 postotna boda u odnosu na njegov dugoročni trend (Basel Committee on Banking Supervision, 2010.), što je u skladu s novijim istraživanjima, jer je jaz omjera kredita i BDP-a u odnosu na dugoročni trend referentan pokazatelj financijske stabilnosti. Jaz omjera kredita i BDP-a koji premašuje svoj dugoročni trend za više od 2 postotna boda, signalizira prekomjernu kreditnu aktivnost banaka te se tada u skladu s protucikličnom makroprudencijalnom politikom, aktiviraju dodatni kapitalni zahtjevi koji obvezuju kreditne institucije na veća regulatorna izdvajanja i na taj način stabiliziraju i vraćaju trend u ciljane okvire (Giese et al., 2013.). Veći regulatorni zahtjevi u vrijeme uzleta u poslovnim ciklusima smanjuju kreditnu aktivnost banaka, tako da smanjuju njihov kreditni potencijal, čime ublažavaju akumulaciju i taloženje rizika.

Obzirom da je Hrvatska narodna banka propisivala visoku stopu adekvatnosti kapitala i prije razvoja krize, bankarski sektor u Hrvatskoj je zadržao stabilnost usprkos financijskim nestabilnostima u zemljama banaka majki te nije došlo do razvoja bankovne krize u Hrvatskoj. Stopa adekvatnosti kapitala od $12 \%$ (HNB, 2013b), bila je znatno viša od one koja je propisana Baselskim sporazumom, a viša stopa adekvatnosti kapitala bila jedan od ključnih elemenata očuvanja stabilnosti financijskoga sustava jer se pokazala djelotvornom usprkos nestabilnostima i poteškoćama izazvanih krizom. Visoka kapitaliziranost bankovnoga sustava važan je čimbenik otpornosti domaćega financijskog sustava na šokove, no i kunski i devizni likvidnosni amortizeri također su imali važnu ulogu u očuvanju financijske stabilnosti. Prema tome, upotreba kapitalnih zahtjeva kao glavnoga instrumenta makroprudencijalne politike, može se smatrati opravdanom iz perspektive pozitivnoga utjecaja na očuvanje financijske stabilnosti. 
Obzirom da monetarna i makroprudencijalna politika koriste instrumente koji djeluju na iste ili povezane varijable, ali u suprotnim smjerovima, može se dogoditi podbačaj jednoga od ciljeva, što znači da idealno rješenje (razina ciljeva) ne postoji; stoga se traži efikasno rješenje koje je onda zadovoljavajuće rješenje problema. Kao mjera odstupanja od očekivanih ciljeva, u ovome radu korištena je varijanca, koja se smatra dobrim pokazateljem uspješnosti provođenja monetarne i makroprudencijalne politike. Pretpostavlja se da regulator raspolaže instrumentima kamatne stope i kapitalnih zahtjeva, uz utjecaj deviznoga tečaja, koje može upotrijebiti za ostvarenje ciljane stope inflacije i ciljane razine omjera kredita i BDP-a (pri čemu je i dinamika rasta omjera kredita i BDP-a iznimno važan pokazatelj financijske stabilnosti).

Ciljevi politika izraženi su funkcijama monetarne i makroprudencijalne politike.

Funkcija cilja monetarne politike prikazana je relacijom: ${ }^{3}$

$$
L^{c b}=\sigma_{I}^{2}+\rho_{\kappa} \sigma_{\Delta \kappa}^{2}+\rho_{T} \sigma_{\Delta T}^{2}
$$

pri čemu je: $L^{c b}$ - funkcija minimizacije odstupanja od zadane razine inflacije $(I=2 \%)$, $\sigma_{I}^{2}$ - varijanca inflacije, $\sigma_{\Delta \kappa}^{2}$ - varijanca promjene kamatne stope i $\sigma_{\Delta T}^{2}$-varijanca promjene deviznoga tečaja, $\rho_{\kappa}$ - parametar inercije prilagodbe kamatne stope, $\rho_{T}$ - parametar inercije prilagodbe deviznoga tečaja.

Funkcija cilja makroprudencijalne politike prikazana je relacijom: ${ }^{4}$

$$
L^{m p}=\sigma_{G}^{2}+\rho_{A} \sigma_{\Delta A}^{2}
$$

pri čemu je: $L^{m p}$ - funkcija minimizacije odstupanja od zadane razine jaza omjera kredita i BDP od dugoročnog trenda $(G<2$ postotna boda od dugoročnoga trenda $), \sigma_{G}^{2}-$ varijanca jaza omjera kredita i BDP-a od dugoročnoga trenda i $\sigma_{\Delta A}^{2}$ - varijanca promjene kapitalnih zahtjeva, $\rho_{A}$ - parametar inercije prilagodbe kapitalnih zahtjeva.

Optimalno ostvarenje ciljeva politika izraženo je minimizacijom funkcije gubitaka $\boldsymbol{L}$ odnosno minimizacijom odstupanja od zadanih ciljeva:

$$
\boldsymbol{L}=L^{c b}+L^{m p}=\sigma_{I}^{2}+\sigma_{G}^{2}+\rho_{\kappa} \sigma_{\Delta \kappa}^{2}+\rho_{A} \sigma_{\Delta A}^{2}+\rho_{T} \sigma_{\Delta T}^{2}
$$

pri čemu je $\sigma_{I}^{2}$ - varijanca inflacije, $\sigma_{G}^{2}$ - varijanca jaza kredita i BDP-a od dugoročnoga trenda, $\sigma_{\Delta \kappa}^{2}$ - varijanca promjene kamatnih stopa, $\sigma_{\Delta A}^{2}$ - varijanca promjene kapitalnih zahtjeva, $\sigma_{\Delta T}^{2}$ - varijanca promjene deviznoga tečaja, $\rho_{\kappa^{\prime}} \rho_{A}, \rho_{T}$ - parametri inercije prilagodbe instrumenata.

Minimiziranjem funkcije gubitka metodom nelinearnog kvadratnog programiranja minimiziraju se gubici provođenja politika u suprotnim smjerovima. Za rješavanje problema optimizacije korištenja instrumenata monetarne i makroprudencijalne politike korišteni su dodaci rješavatelja u sklopu proračunskih tablica programa MS Excel.

Da bi ukupni učinak provođenja politika bio što učinkovitiji, potrebno je minimizirati odstupanja od funkcija cilja monetarne $\left(L^{c b}\right)$ i makroprudencijalne politike $\left(L^{m p}\right)$.

Model koji je prikazan u ovome radu analizira učinkovitost monetarne i makroprudencijalne politike u dva slučaja:

Prema Angelini i sur. (2012.).

Prema Angelini i sur. (2012.). 
a) u kooperativnome slučaju; monetarna i makroprudencijalna politika istodobno koriste svoje instrumente za postizanje ciljeva cjenovne i financijske stabilnosti

b) u ne-kooperativnome slučaju; monetarna politika koristi instrument kamatnu stopu za postizanje cjenovne stabilnosti, uz zadanu razinu kapitalnih zahtjeva, a makroprudencijalna politika koristi instrument kapitalni zahtjevi za postizanje financijske stabilnosti, uz zadanu razinu kamatne stope.

U oba slučaja u model je uvrštena varijabla devizni tečaj jer je model kreiran na primjeru Hrvatske gdje devizni tečaj ima značajan utjecaj na provođenje monetarne politike te cjenovnu i financijsku stabilnost.

Razdoblje obuhvaćeno analizom je razdoblje od 2000. godine do 2015. godine, a podaci su prikupljeni na godišnjoj razini.

Tablica 2: Ciljevi i instrumenti monetarne i makroprudencijalne politike korišteni u modelu

\begin{tabular}{|l|l|l|}
\hline & \multicolumn{1}{|c|}{ Ciljevi } & \multicolumn{1}{|c|}{ Instrumenti } \\
\hline MONETARNA POLITIKA & cjenovna stabilnost $(I \leq 2 \%)$ & $\begin{array}{l}\text { kamatna stopa } \\
\text { devizni tečaj }\end{array}$ \\
\hline $\begin{array}{l}\text { MAKROPRUDENCIJALNA } \\
\text { POLITIKA }\end{array}$ & $\begin{array}{l}\text { financijska stabilnost }(G \leq 2 \text { postotna } \\
\text { boda od dugoročnoga trenda })\end{array}$ & $\begin{array}{l}\text { kapitalni zahtjevi } \\
\text { devizni tečaj }\end{array}$ \\
\hline
\end{tabular}

Izvor: prikaz autorica.

Monetarna politika određuje razinu kamatnih stopa $K_{t}^{5}$ prema Taylorovom pravilu (Taylor, 1993.). Zbog utjecaja deviznoga tečaja, u ovome radu Taylorovo pravilo prošireno je varijablom devizni tečaj:

$$
\begin{gathered}
K_{t}=\left(1-\rho_{K}\right) \bar{K}+\left(1-\rho_{K}\right)\left[\chi_{I}\left(I_{t}-\bar{I}\right)\right]+\rho_{k} K_{t-1}+\left(1-\rho_{T}\right) \bar{T} \\
+\left(1-\rho_{T}\right)\left[\chi_{I}\left(I_{t}-\bar{I}\right)\right]+\rho_{T} T_{T-1}
\end{gathered}
$$

pri čemu je $\bar{\kappa}$ prosječna kamatna stopa, $\bar{T}$ - prosječni devizni tečaj, $\bar{I}$ - prosječna inflacija, $I_{t}$ - inflacija u godini t, $\chi_{\bar{I}}$ - parametar osjetljivosti ciljane inflacije, $\rho_{K}$ - parametar inercije prilagodbe kamatne stope i $\rho_{T}$ - parametar inercije prilagodbe deviznoga tečaja.

Makroprudencijalna politika koristi kapitalne zahtjeve $\left(A_{t}\right)$ za očuvanje financijske stabilnosti:

$$
A_{t}=\left(1-\rho_{A}\right) \bar{A}+\left(1-\rho_{A}\right) \chi_{A} G_{t}+\rho_{A} A_{t-1},
$$

pri čemu su $\bar{A}$ - prosječni kapitalni zahtjevi, $\rho_{A}$ - parametar inercije prilagodbe kapitalnih zahtjeva, $\chi_{A}$ - parametar osjetljivosti jaza omjera kredita i BDP-a od dugoročnoga trenda, $G_{t}-$ jaz omjera kredita i BDP-a od dugoročnoga trenda.

Kamatna stopa - ZIBOR 6. mj.* jedinstvena kamatna referentna stopa na hrvatskome međubankarskom tržištu kao cijena zaduživanja banaka pokazala je da spuštanjem eskontne stope i visine stope zakonske zatezne kamatne te nulta-kamatna stopa na prekonoćne depozite banaka kod središnje banke utječu na djelovanje kanala kamatnjaka u Hrvatskoj (Ivanov, 2014.). 
Temeljem unosa poznatih vrijednosti u model (3) dobivene su vrijednosti parametara inercije prilagodbe instrumenata i vrijednosti parametara osjetljivosti ciljeva posebno za kooperativni, a posebno za ne-kooperativni model (tablica 4. i tablica 5.).

U kooperativnome modelu istodobno se minimiziraju odstupanja svih parametara prilagodbe i osjetljivosti s ciljem očuvanja stabilnosti cijena i očuvanja stabilnosti jaza omjera kredita i BDP-a od dugoročnoga trenda (7):

$$
\left(\chi_{P}, \chi_{y}, \rho_{K}, \rho_{T} ; \chi_{A}, \rho_{A}\right)=\arg \min L\left(\chi_{P}, \chi_{y}, \rho_{K}, \rho_{T} ; \chi_{A}, \rho_{A}\right)
$$

Tablica 4. Parametri kooperativnoga modela

\begin{tabular}{|c|c|}
\hline Parametri & Vrijednosti parametara (7) \\
\hline$\rho_{K}$ & 0,079547 \\
\hline$\rho_{T}$ & 0,996243 \\
\hline$\chi_{I}$ & 0,492812 \\
\hline$\rho_{A}$ & $-0,27736$ \\
\hline$\chi_{a}$ & 0,971823 \\
\hline
\end{tabular}

Izvor: izrada autorica.

U ne-kooperativnome modelu izolirano se primjenjuju:

- kamatna stopa i devizni tečaj u svrhu minimizacije odstupanja stope inflacije, pri čemu su kapitalni zahtjevi fiksni (8)

$\left(\chi_{r}, \chi_{y}, \rho_{K}, \rho_{T}\right)=\arg \min L\left(\chi_{r}, \chi_{y}, \rho_{K}, \rho_{T} ; \chi_{A}, \rho_{A}\right)$

- kapitalni zahtjevi u svrhu očuvanja stabilnosti jaza omjera kredita i BDP-a od dugoročnoga trenda pri čemu su kamatna stopa i devizni tečaj fiksni (9)

$\left(\chi_{A}, \rho_{A}\right)=\arg \min L\left(\chi_{P}, \chi_{y}, \rho_{K}, \rho_{T} ; \chi_{a}, \rho_{A}\right)$

Tablica 5. Parametri ne-kooperativnoga modela

\begin{tabular}{|c|c|c|}
\hline Politike & Parametri & Vrijednosti parametara (8) i (9) \\
\hline \multirow{3}{*}{ Monetarna politika } & $\rho_{K}$ & $-0,19289$ \\
\cline { 2 - 3 } & $\rho_{T}$ & 0,995131 \\
\cline { 2 - 3 } & $\chi_{I}$ & 0,342692 \\
\hline \multirow{2}{*}{$\begin{array}{c}\text { Makroprudencijalna } \\
\text { politika }\end{array}$} & $\rho_{A}$ & $-0,02156$ \\
\cline { 2 - 3 } & $\chi_{a}$ & 0,977466 \\
\hline
\end{tabular}

Izvor: izrada autorica.

Dobiveni parametri za kooperativni i za ne-kooperativni model uvršteni su u modele (4) i (5) te su dobivene vrijednosti odstupanja ciljeva $\left(\sigma_{I}\right)$ i $\left(\sigma_{G}\right)$ posebno za kooperativni i posebno za nekooperativni model.

Odstupanja od ciljanih vrijednosti inflacije i omjera kredita i BDP-a od dugoročnoga trenda prikazane su u obliku standardnih devijacija u tablici 6. 
Tablica 6. Standardna devijacija inflacije $\left(\sigma_{I}\right)$ i standardna devijacija jaza omjera kredita i BDP-a od dugoročnoga trenda $\left(\sigma_{G}\right)$

\begin{tabular}{|c|c|c|}
\hline & Kooperativni model & Ne-kooperativni model \\
\hline$\sigma_{I}$ & 4,835 & 6,163 \\
\hline$\sigma_{G}$ & 2,543 & 2,577 \\
\hline
\end{tabular}

Izvor: izrada autorica.

Rezultati istraživanja pokazuju da se optimalna koordinacija monetarne i makroprudencijalne politike postiže minimiziranjem odstupanja od funkcija cilja za monetarnu i makroprudencijalnu politiku. Minimizacijom odstupanja koja su ustvari gubici provođenja neoptimalne razine politika, dokazano je da monetarna i makroprudencijalna politika imaju veću učinkovitost ako svoje instrumente koriste koordinirano u kooperativnome modelu, prilikom čega koriste kamatnu stopu, kapitalne zahtjeve i devizni tečaj (za male otvorene i visokoeuroizirane zemlje poput Hrvatske) za istodobno ostvarenje stabilnosti cijena (kao cilj monetarne politike) i financijske stabilnosti mjerenu omjerom kredita i BDP-a (kao cilj makroprudencijalne politike). Dokazana veća učinkovitost kooperativnoga modela primjene monetarne i makroprudencijalne politike u skladu je s rezultatima istraživanja koordinacije monetarne i makroprudencijalne politike koje su proveli Angelini i sur. (2012.). Također, dobiveni rezultati sukladni su rezultatima istraživanja o učincima kombinirane primjene protucikličnih kapitalnih zahtjeva i restriktivne monetarne politike na ograničenja korištenja poluge u bankovnome sustavu koje su dobili Angeloni i Faia (2009.) i Derviz (2013.).

\section{ZAKLJUČAK}

Model u kojemu monetarna i makroprudencijalna politika kooperativno surađuju tako da se instrumenti monetarne (kamatna stopa) i makroprudencijalne politike (adekvatnost kapitala) uz utjecaj deviznoga tečaja koriste istodobno u svrhu zajedničkoga ostvarenja oba cilja pokazao je da su u slučaju suradnje politika, odstupanja oba cilja od zadane razine manja $\left(\sigma_{I}=4,835, \sigma_{G}=2,543\right)$ od odstupanja inflacije i varijance odstupanja jaza omjera kredita i BDP-a od dugoročnoga trenda kada se u modelu izolirano primjenjuju posebno instrumenti monetarne, a posebno makroprudencijalne politike $\left(\sigma_{I}=6,163, \sigma_{G}=2,577\right)$. Prema tome, razvidno je da je usprkos ograničenjima monetarne politike u slučaju malih otvorenih ekonomija obilježenih visokom uvoznom ovisnošću i visokim stupnjem euroizacije, kooperativno provođenje monetarne i makroprudencijalne politike učinkovitije od izoliranoga pristupa, jer se središnja banka zbog visokoga stupnja euroizacije kredita i depozita mora usredotočiti na očuvanje stabilnosti deviznoga tečaja što ograničava aktivnost i učinkovitost monetarne politike. Istraživanjem je dokazano da primjena makroprudencijalnih instrumenta pozitivno utječe na očuvanje stabilnosti financijskoga sustava ako se primjenjuje model u kojemu monetarna i makroprudencijalna politika kooperativno koriste svoje instrumente za zajedničko ostvarenje svojih ciljeva. Dobiveni rezultati mogu poslužiti užoj znanstvenoj i stručnoj javnosti koja se bavi problematikom monetarne politike i analize, a obzirom da je u model uveden devizni tečaj, rezultati istraživanja posebno su važni 
za Hrvatsku, ali se takav model može primijeniti i za druga mala otvorena gospodarstva sličnih makroekonomskih značajki.

Ipak, provedeno istraživanje ima i određena ograničenja kao što su nedostupnost i neobjavljivanje svih potrebnih podataka u jednakim vremenskim razdobljima, što je rezultiralo provođenjem istraživanja na godišnjoj razini. Preporuka budućim istraživačima je provesti istraživanje po kvartalima ako podaci budu dostupni. Nadalje, ograničenje koje se pojavilo odnosi se na funkcioniranje kanala kamatne stope u Hrvatskoj. Naime, kanal kamatne stope uglavnom nije djelovao u vrijeme ekspanzije kreditnih i poslovnih ciklusa, već se njegov učinak počinje javljati nakon razvoja krize (poslije 2008. godine). Prema tome, daljnja istraživanja će snažnije pokazati značenje zajedničkoga djelovanja monetarne i makroprudencijalne politike korištenjem instrumenata kamatne stope. Osim toga, u postojeći model mogu se uključiti dodatne varijable, ovisno o fazi kreditnih i poslovnih ciklusa i s tim povezanim odabirom instrumenata monetarne i makroprudencijalne politike.

\section{LITERATURA:}

1. Adrian, T., Shin, H. S., (2009). Money, liquidity and monetary policy. Federal Reserve Bank of New York Staff Reports, no. 360, https://www.newyorkfed.org/medialibrary/ media/research/staff_reports/sr360.pdf, (pristupljeno 8. 4. 2016.).

2. Agur, I., Demertzis, M. (2012). Excessive bank risk taking and monetary policy, $E C B$ Working papers, br. 1457, https://www.ecb.europa.eu/pub/pdf/scpwps/ecbwp1457. pdf?e0eea99cecbbe5262be5071c5db9eded, (pristupljeno 11. 5. 2016.).

3. Altunbas, Y., Gambacorta, L., Marques-Ibanez, D. (2014). Does Monetary Policy Affect Bank Risk, International Journal of Central Banking, Vol. 10, No. 1, str. http:// www.ijcb.org/journal/ijcb14q1a3.pdf, (pristupljeno 29. 9. 2016.).

4. Angelini, P., Neri, S., Panetta, F. (2012). Monetary and macroprudential policies, ECB Working paper, br. 1449, https://www.ecb.europa.eu/pub/pdf/scpwps/ecbwp1449. pdf?b61cbb31d8b42f7c125bde5332c95005, (pristupljeno 18. 4. 2016.).

5. Angeloni, I., Faia, E. (2009). A Tale of Two Policies: Prudential Regulation and Monetary Policy with Fragile Banks, Kiel Institute for the World Economy, Working Paper, br. 1569, https://www.snb.ch/n/mmr/reference/sem_2009_09_25_faia/source/ sem_2009_09_25_faia.pdf, (pristupljeno 8. 4. 2016.).

6. Bank for International Settlement (2011). Progress Report to G20, Macroprudential Policy Tools and Frameworks, http://www.bis.org/publ/othp17.pdf, (pristupljeno 10. 5. 2016.).

7. Basel Committee on Banking Supervision (2010). Countercyclical capital buffer proposal, Consultative Document, Issued for comment by 16 April 2010, http://www.bis. org/publ/bcbs164.pdf, (pristupljeno 19. 4. 2016.).

8. Benes, J., Laxton, D., Mongardini, J. (2016). Mitigating the Deadly Embrace in Financial Cycles: Countercyclical Buffers and Loan-to-Value Limits, IMF Working Paper, br. 1687, http://www.imf.org/external/pubs/ft/wp/2016/wp1687.pdf, pristupljeno 18. 4. 2016.). 
9. Borio, C., Zhu, H. (2008). Capital regulation, risk-taking and monetary policy: a missing link in the transmission mechanism?, BIS Workin papers br. 268, http://www.bis. org/publ/work268.htm, (pristupljeno 10. 5. 2016.).

10. Brzoza-Brezina, M., Kolasa, M., Makarski, K. (2015). Monetary and macroprudential policy with foreign currency loans, ECB, Makroprudential Research Network, https:// www.ecb.europa.eu/pub/pdf/scpwps/ecbwp1783.en.pdf?3ca578c19ca00ca85d62a0eec39da19a, (pristupljeno 18. 4. 2016.).

11. Canuto, O., Cavallari, M. (2013). Asset Prices, Macroprudential Regulation, and Monetary Policy, The World Bank, Poverty reduction and economic management network, br. 116, http://siteresources.worldbank.org/EXTPREMNET/Resources/EP116.pdf, (pristupljeno 12. 4. 2016.).

12. De Paoli, B., Paustian, M. (2013). Coordinating Monetary and Macroprudential Policies, Federal Reserve Bank of New York Staff Reports, br. 653, https://www.newyorkfed.org/ medialibrary/media/research/staff_reports/sr653.pdf, (pristupljeno 18. 4. 2016.).

13. Derviz, A. (2013). Bubbles, bank credit and macroprudential policies, Macroprudential research netvork, ECB Working paper, br 1551, https://www.ecb.europa.eu/pub/ pdf/scpwps/ecbwp1551.pdf?d971aacc1e2e148b8f70ce4d0cea09dc, (pristupljeno 12. 4. 2016.).

14. European Systemic Risk Bord (2013). The ESRB Handbook on Operationalising Macro-prudential Policy in the Banking Sector, https://www.esrb.europa.eu/pub/pdf/other/140303_esrb_handbook_mp.en.pdf, (pristupljeno 28. 9. 2016.).

15. European central bank (2016). Macroprudential Bulletin, br. 1, ožujak 2016, https:// www.ecb.europa.eu/pub/pdf/other/ecbmpbu201603.en.pdf, (pristupljeno 18. 4. 2016.).

16. Fratzscher, M. (2012). Capital controls and foreign exchange policy, ECB Working paper series, br. 1415, http://www.ecb.europa.eu/pub/pdf/scpwps/ecbwp1415.pdf, (pristupljeno 10. 5. 2016.).

17. Gertler, M., Karadi, P. (2011). A model of unconventional monetary policy, Journal of Monetary Economics, br. 58, str. 17-34.

18. Giese, J., Andersen, H., Bush, O., Castro, C., Farag, M., Kapadia, S. (2013). The creditto-GDP gap and complementary indicators for macroprudential policy: Evidence from the UK, International Journal of Finance \& Economics, Vol. 19, br. 1, str. 25-47.

19. Hartmann, P. (2015). Real estate markets and macroprudential policy in Europe, ECB Working Paper Series, br. 1796, https://www.ecb.europa.eu/pub/pdf/scpwps/ ecbwp1796.en.pdf?0d3ffa44eff6f4aad8672fd492d87a3d, (pristupljeno 18. 4. 2016.).

20. Hrvatska narodna banka (2016.). Pregled mjera i instrumenata monetarne politike, http://old.hnb.hr/monet/hmonet.htm, (pristupljeno 27. 9. 2016.).

21. Hrvatska narodna banka (2013.a). Financijska stabilnost, broj 11, http://old.hnb.hr/ publikac/financijska\%20stabilnost/h-fs-11-2013.pdf, (pristupljeno 27. 4. 2016.).

22. Hrvatska narodna banka (2013.b). Odluka o adekvatnosti jamstvenog kapitala kreditnih institucija, dostupno na: http://old.hnb.hr/propisi/odluke-nadzor-kontrola/odluke-zoki-ozujak-2010/h-odluka-o-adekvatnosti-jamstvenoga-kapitala-ki-od\%2030-62012.pdf, [29. 4. 2016.]. 
23. Hrvatska udruga banaka (2009.). Monetarna transmisija: Sve počinje i završava s bankama, HUB Analize br. 17, http://www.arhivanalitika.hr/dat/HUB\%20Analiza\%2017. pdf, (pristupljeno 10. 5. 2016.).

24. International monetary fund (2013a). Key aspects of macroprudential policy, prepared by Brockmei, J., approved by Vinals, J., http://www.imf.org/external/np/pp/eng/2013/061013b.pdf, (pristupljeno 13. 4. 2016.).

25. International monetary fund (2013b). The interaction of monetary and macroprudential policies prepared by Claessens, S., Habermeier, K., Nier., E., Kang, H., Mancini-Griffoli, T., Valencia, F., approved by Blanchard, O., Vinals, J. https://www.imf.org/ external/np/pp/eng/2013/012913.pdf, (pristupljeno 12. 4. 2016.).

26. International monetary fund (2014). Staff guidance note on macroprudential policy, prepared by Nier, E., approved by Vinals, J, Tiwari, S., http://www.imf.org/external/ np/pp/eng/2014/110614.pdf, (pristupljeno 13. 4. 2016.).

27. Ito, T, Sato, K. (2006). Exchange rate changes and inflation in post-crisis Asian economies: VAR analysis of the exchange rate pass-through, National bureau of economic research Working paper 12395, http://www.nber.org/papers/w12395.pdf, (pristupljeno 25. 8. 2014.).

28. Ivanov, M. (2014.). Kontraciklična monetarna politika u Hrvatskoj, Zbornik radova znanstvenog skupa „Razvojni potencijali hrvatskog gospodarstva“, (ur. Družić, G.; Družić, I., izdavač: Ekonomski fakultet Zagreb; Hrvatska akademija znanosti i umjetnosti), https://ideas.repec.org/h/zag/chaptr/14-04.html, (pristupljeno 28. 9. 2016.).

29. Kannan, P., Rabanal, P., Scott, A. (2009). Monetary and Macroprudential Policy Rules in a Model with House Price Booms, IMF Working Paper br. 251, https://www.imf.org/ external/pubs/ft/wp/2009/wp09251.pdf, (pristupljeno 11. 4. 2016.).

30. Kiyotaki, N., Moore, J. (2008). Liquidity, business cycles and monetary policy, rad prezentiran na konferenciji „Financial Cycles, Liquidity and Securitization Conference“, Washington, DC, 18. travnja 2008., dostupno na: https://www.imf.org/external/np/ seminars/eng/2008/fincycl/pdf/kimo.pdf, (pristupljeno 8. 4. 2016.).

31. Lim, Columba, F., Costa, A., Kongsamut, P., Otani, A., Saiyid, M., Wezel, T., Wu, X. (2011). Macroprudential Policy: What Instruments and How to Use Them?, IMF Working Paper br. 238, https://www.imf.org/external/pubs/ft/wp/2011/wp11238.pdf, (pristupljeno 27. 4. 2016.).

32. Lovrinović, I., Ivanov, M. (2009.). Monetarna politika, RRIF, Zagreb.

33. N'Diaye, P. (2009). Countercyclical macro prudential policies in a supporting role to monetary policy, IMF Working paper br. 257., https:/www.imf.org/external/pubs/ft/ wp/2009/wp09257.pdf, (pristupljeno 8. 4. 2016.).

34. Nikolov, K. (2012). A model of borrower reputation as intangible collateral, ECB Working paper series br. 1490, https://www.ecb.europa.eu/pub/pdf/scpwps/ecbwp1490. pdf?471ae9e035d529b78b66f275ca8dc1d1, (pristupljeno 8. 4. 2016.).

35. Posedel, P., Tica, J. (2007). Threshold Autoregressive Model of Exchange Rate Pass through Effect: The Case of Croatia, Ekonomski fakultet Zagreb Working paper series, br. 07-15, http://www.researchgate.net/publication/23754736_Threshold_Autoregressive_Model_of_Exchange_Rate_Pass_through_Effect_The_Case_of_Croatia/links/02e7e52ab1ac834ad8000000, (pristupljeno 25. 8. 2014.). 
36. Radošević (2010.). Strategija liberalizacije kapitalnih tokova Hrvatske s inozemstvom Ekonomski pregled, 61 (12), str. 725-768. (2010.).

37. Radošević, D. (2013.) Financijalizacija periferije Europske Unije, kapitalne kontrole i platna bilanca, Ekonomija: časopis za ekonomsku teoriju i politiku, Rifin, ISSN 13300636, Vol. 20., 2013, 1, str. 131-151.

38. Taylor, J. B. (1993). Discretion versus policy rules in practice, rad prezentiran na konferenciji „Carnegie-Rochester Conference Series on Public Policy 39“, North-Holland, str. 195-214., http://web.stanford.edu/ johntayl/Papers/Discretion.pdf, (pristupljeno 8. 5. 2016.).

39. Uredba o izmjeni Zakona o deviznom poslovanju (2009.). Narodne novine, br. 153/2009., http://narodne-novine.nn.hr/clanci/sluzbeni/2009_12_153_3762.html, (pristupljeno 26. 9. 2016.).

40. Zakon o deviznom poslovanju, Narodne novine, br. 96/2003., http://narodne-novine. nn.hr/clanci/sluzbeni/2003_06_96_1217.html, (pristupljeno 26. 9. 2016.).

41. Zakon o izmjenama i dopunama zakona o deviznom poslovanju, Narodne novine, br. 132/2006., http://narodne-novine.nn.hr/clanci/sluzbeni/2006_12_132_2955.html, (pristupljeno 26. 9. 2016.).

42. Zakon o kreditnim institucijama, Narodne novine, br. 117/2008., http://narodne-novine. nn.hr/clanci/sluzbeni/341916.html, (pristupljeno 27. 9. 2016.).

43. Zakon o kreditnim institucijama, Narodne novine, br. 159/2013., http://narodne-novine. nn.hr/clanci/sluzbeni/2013_12_159_3328.html, (pristupljeno 27. 9. 2016.). 